\title{
Dizer DEUS E O HuMANO NO \\ CONTEXTO da Pós-Modernidade
}

\author{
SAYING GOD AND THE HUMAN IN THE \\ CONTEXT OF POST-MODERNITY
}

Cleusa Caldeira *

\begin{abstract}
RESUMO
O contexto pós-moderno está marcado pela forte crise de sentido que experimenta os indivíduos, depois do colapso do sujeito moderno e a emergência da vulnerabilidade. Existem inúmeras interpretações desta vulnerabilidade, da mesma forma que multiplicam os contextos e seus sujeitos. Esta nova subjetividade, marcada pela aguda consciência da finitude, da culpabilidade e da possibilidade de redenção que chega pela alteridade amorosa, torna-se o solo fecundo para pensar e dizer a experiência de Deus e do humano. Nesse horizonte, este texto se propõe a apresentar duas versões de teologias cristãs em tempos de fragmentos, que nos coloca em contato com a pluralidade de aproximação ao mistério humano-divino no contexto da pós-modernidade.

Palavras-chave: Teologias pós-modernas. Vulnerabilidade. Mistério humano-divino.
\end{abstract}

\section{ABSTRACT}

The postmodern context is marked by the strong crisis of meaning experienced by individuals after the collapse of the modern subject and the emergence of vulnerability. There are many interpretations of this vulnerability, in the same way that the contexts and their subjects multiply. This new subjectivity, marked by the acute awareness of finitude, guilt and the possibility of redemption that comes from the otherness of love, becomes the fruitful ground to think and say the experience of God and the human. On this horizon, this text proposes to present two versions of Christian theologies in times of fragments, which puts us in contact with the plurality of approach to the human-divine mystery in the context of postmodernity.

Keywords: Postmodern theologies. Vulnerability. Human-divine mystery.

\section{INTRODUÇÃO}

Diante da crise que se instaurou com o colapso do sujeito autônomo, atestado tanto com o horror do Holocausto quanto pela queda das Torres Gêmeas, a teologia se vê desafiada a justificar a existência humana diante de tantos gestos de desumanidade. Nesse novo contexto marcado pela derrocado do sujeito moderno em sua pretensão de autossuficiência, emerge a racionalidade pós-moderna ${ }^{1}$ com sua afirmação da vulnerabilidade constitutiva da

\footnotetext{
* Doutora, mestra e bacharel em Teologia, e pós-doutoranda em teologia pela Pontifícia Universidade Católica do Paraná. Exerce o ministério pastoral na Igreja Presbiteriana Independente do Brasil. Bolsista CAPES. Email: cleucaldeira@gmail.com ORCID: http://orcid.org/oooo-0001-7202-0682.

${ }^{1}$ Não existe um consenso em relação ao conceito de "pós-modernidade". Entretanto, sem entrar no debate aberto sobre o que venha a ser a pós-modernidade, denotamos que a acepção de pós-modernidade em questão está fortemente marcada pela consciência do esgotamento da modernidade ilustrada, sobretudo a versão técnico-científica que desencadeou o caos planetário e ecológico que coloca em risco o futuro da
}

INTERAÇÕES, Belo Horizonte, Brasil, v. 14, n. 25, p. 186-204, jan./jun. 2019

ISSN 1983-2478 
subjetividade como único modo-de-ser. Surgem, portanto, diversas teologias cristãs pósmodernas que procuram dar conta de dizer Deus e o humano no marco da irrupção da nova racionalidade.

Isso significa assumir que a reflexão teológica, como todo pensamento, encontra-se enraizada num tempo e contexto. Por esta razão não podemos falar de teologia no singular, mas de teologias. Essa característica plural do pensamento e da ação é constitutiva da racionalidade pós-moderna, visto que se atestou o fim dos metarrelatos de totalidade; que aceita apenas balbucios sobre os escombros do eu ensimesmado. A assunção, pois, da contextualidade do pensamento ajuda-nos a manter uma postura cordial diante do outro, do diferente. Ao contrário da razão técnico-científica, que afirma o caminho unívoco à verdade, a pós-modernidade sob o logos digital afirma as múltiplas formas de aproximação do real e, consequentemente, da construção do sentido e da verdade capaz de salvar. Por outro lado, isso constituiu difícil e necessário exercício à teologia, sobretudo à teologia conservadora e hegemônica, visto que historicamente ela se apresentou como portadora da verdade absoluta e, por isso, se autodefinia como regina scientiarum (MENDOZA, 2008, p. 28), afirmando que o ser, o sentido e a verdade são dados de antemão.

Afirmar a universalidade da fé cristã em contexto pós-moderno passa pela "radicalização" da razão secular, em uma postura crítica e consciente de seus excessos e, também, de suas potencialidades, de tal modo que resulte numa verdade teológica capaz de proporcionar esperança no futuro possível para todos. Nesse horizonte, descrevemos duas teologias cristãs como possibilidades novas de falar de Deus e do humano. Uma se inscreve na corrente teológica que rechaça a secularização, e a outra assume até o extremo a autonomia das realidades terrestres. Uma se inscreve num cristianismo pós-secular, a outra num cristianismo pós-moderno.

O primeiro discurso teológico está assinado pelo teólogo e coreógrafo mexicano Ángel Francisco Méndez Montoya; encontra-se condensado no livro Festín del deseo: hacia una teología alimentaria (MONTOYA, 2010)², elaborado na cozinha, mais especificamente “embaixo de uma mesa”, isto é, a partir do ser que tem fome, da subjetividade vulnerável que habita sua indigência com um gesto de resiliência que a todos alimenta. Em 2017, tive o

humanidade e do planeta. Longe de renunciar às conquistas da modernidade, o que se busca é uma consciência voltada para o seu próprio ultrapassamento, capaz de suscitar uma nova maneira de ser-nomundo (CALDEIRA, 2017, p. 819).

2 Todas as citações literais do autor serão tradução nossa. 
privilégio de ver a performance do coreógrafo em uma apresentação única no Brasil, quando ele pôde encarnar sua teologia em uma dança que nos desafiou a fazer teologia a partir daquelas subjetividades vulneráveis e vulneradas que esperam pelas migalhas em baixo da mesa, seguindo a metáfora viva da mulher sírio-fenícia (cf. Mateus 15, 21-28).

O segundo discurso teológico foi desenvolvido a partir da recepção criativa da teoria do desejo mimético de René Girard; está assinado pelo teólogo britânico em diáspora James Alison, que descreve uma escatologia pós-moderna. Com isso, Alison busca dar conta de dizer como acontece a redenção no seio da intersubjetividade, que se debate entre rivalidade e gratuidade. Trata-se de descobrir como acontece a revelação de Deus em meio os processos de rivalidade, quando a subjetividade consegue assumir a lógica da doação análoga à experiência de Jesus de Nazaré, isto é, quando a subjetividade de posse da "inteligência da vítima” se descobre incondicionalmente amada por Deus.

Em suma, com esta breve apresentação desejamos cavar em cada um o desejo de ler as obras no original, para que experimente o gozo de ver e compreender o que eu não consegui por causa do meu próprio contexto, que me possibilita, mas também interdita. Cabe pontuar, minha breve aproximação a essas teologias se deu primeiro por intermédio da obra teológica do mexicano Carlos Mendoza Álvarez³, de modo que o citarei sempre que necessário, para uma melhor compreensão das teologias supracitadas.

\section{TEOLOGIA ALIMENTÁRIA: QUE NINGUÉM PASSE FOME}

Ligado ao pensamento teológico da Ortodoxia Radical4, Ángel Francisco Méndez Montoya desenvolve uma teologia alimentária com o objetivo de reconstruir o vínculo com a transcendência que - segundo essa corrente teológica - a crítica da razão renunciou. Com essa renúncia, sacrificou-se também a ideia de fundamento teológico do mundo, isto é, chegou ao fim a unanimidade de uma visão heterônoma do mundo, pois o novo axioma estabelecido com a modernidade - a autonomia da inteligência humana - usurpou o lugar de Deus na criação. E, assim, acabou se estabelecendo a violência como lei da história, afirma John Milbank (1995). Agora, diante do colapso da modernidade, sobretudo depois de Auschwitz e, por último, a queda das Torres Gêmeas, que atestaram o naufrágio do ego

\footnotetext{
3 No corpo do texto, optaremos por citar este autor da forma como ele é mais conhecido no Brasil, isto é, Carlos Mendoza. Abaixo, nas Referências, segue o nome completo, de acordo com as obras consultadas.

4 Para uma maior aproximação ao pensamento da Ortodoxia Radical, ver: ESTRADA. In: ZEPEDA, 2010, p. 99-119.
} 
moderno, a teologia pós-secular defende à “volta ao fundamento" metafísico como resolução do enigma da violência. Em outras palavras, essa corrente teológica nega a secularização e postula uma sociedade nova chamada de "pós-secular", sob a ideia de uma "livre teocracia" capaz de garantir a paz transcendental (MENDOZA, 2015, p. 328). Esse pensamento "póssecular" suscita novamente a necessidade de uma fundamentação transcendente da liberdade e da razão humana, assim como de todos os entes, e, também, da sacralidade inerente da criação.

É neste marco epistemológico da razão pós-secular que radica a teologia alimentária de Montoya, propondo como superação da secularização da razão, a ontologia do Ser Sofiânico5. Uma teologia do alimento, tanto em sua dimensão de generosidade simbólica e ação de compartilhar que nutre o corpo e o espírito, como o símbolo e paradigma por excelência da íntima relação de Deus com a humanidade (MONTOYA, 2008, p. 55). Fazendo uso do mollí ${ }^{6}$ hibrido como metáfora culinária, Montoya busca ampliar a imaginação teológica em relação ao pensar e ao falar sobre Deus em contexto pós-secular. Ele busca repensar a prática da Eucaristia que, segundo ele, não tem a ver somente com a razão, com a fé e com a doutrina. Mas, também é resultado da conjugação de elementos ou ingredientes complexos, como o corpo e os sentidos, a materialidade e o Espírito, a cultura, a construção de significados e uma mescla humano-divino de desejos. Degustemos, pois, dois aspectos da teologia alimentária, preparada em baixo da mesa: o Ser Sofiânico, e a teo-política da superabundância.

\footnotetext{
5 Montoya segue Sergei Bulgakov, que é fascinado pela personificação da Sofia, pois ele crê que todo ser humano contém em si mesmo a conexão orgânica da humanidade com Deus, e que esta conexão procede da beleza harmônica do aspecto sofiânico da divindade (MONTOYA, 2010, p. 173).

${ }^{6} \mathrm{O}$ molli é um tradicional prato mexicano que pode conter de cinco a 33 ingredientes e leva cerca de 12 horas para se prepará-lo. Ao final da preparação todos os ingredientes são moídos, resultando assim no "molli" em pó. Há inúmeras narrativas populares para a origem do molli, desde as cozinhas dos conventos femininos passando por monastério masculino do México barroco colonial. Pesquisas recentes apontam que o molli já era parte da cozinha pré-hispânica. Certo é que o molli é um híbrido cultural. A origem do mole remonta ao mundo mexica, à cozinha dos chamados mexicas da cidade de Tenochtitlan. No imaginário dos mexicas, comer molli cujos ingredientes simbolizam diversas deidades, era uma forma de alimentar-se dos deuses, que por sua vez comiam os humanos no momento de sua morte. O molli era mais que uma alimentação comum, era considerado "uma comida dos deuses, uma comida divina". Esse tradicional prato mexicano resistiu ao processo de extermínio do "encobrimento" europeu. Porém, a hibridação das raças, das práticas culturais, sociais, políticas e religiosas do período colonial se estendeu também à alimentação, e por sua vez ao molli. O molli, além da dimensão lúdica da existência, traz também a dimensão de luta e subversão. Isso se evidencia, na época barroca do México, quando mulheres eram proibidas de atuar no espaço público e eram confinadas ao espaço da cozinha; a cozinha se transformou em espaço de resistência (MONTOYA, 2010, p. 41-64).
} 


\subsection{O Ser Sofiânico: o Ser alimentado}

Seguindo o teólogo russo Sergei Bulgakov, o teólogo mexicano se apropria da figura

bíblica de Sofia7 para descrever o ser relacional como excesso e superabundância. Sofia é, pois, o paradigma de uma economia do desejo redimido, no qual a Eucaristia é o cume da transfiguração e participação na vida intradivina, isto é, inclusão na plena relacionalidade. Na Eucaristia há uma comunhão de desejos: nela se encontram o desejo de Deus de partilhar a divindade com a humanidade e o desejo da humanidade em relação a Deus. Nesse horizonte, a nossa deificação acontece por meio dos nossos corpos e da experiência sensual no banquete eucarístico promovido pela Sofia, que nos instrui sobre o compartilhar metafísico do Ser de Deus; na plena relacionalidade vivida na comunidade trinitária.

Partindo de análises dos textos bíblicos ${ }^{8}$, o teólogo mexicano afirma que a Sofia não apenas oferece um banquete, mas se oferece ela mesma como dom que alimenta e aproxima a Deus em seu nutrir. Nesse banquete, no qual Sofia se dá, há uma profunda unidade entre humano e divino, onde imanência e transcendência se abraçam e se beijam:

No baquete de Sofia a matéria é transfigurada por um ato de doação transcendente, no qual não elimina senão que nutre a imanência. Sofia é a artista culinária que prepara um banquete onde a imanência e a transcendência entram em uma relação alquímica que produz intercomunhão: o espaço intermédio onde Eros e Ágape entram em uma economia de desejos e doações mútuas (MONTOYA, 2008, p. 56).

Nesta relação erótico-agapeica, o Eros e o Ágape não se excluem. Antes, eles se complementam mutuamente, pois o Ser é simultaneamente erótico e ágapeico: o Ser permanece sempre aberto à alteridade, em um eterno appetitus pelo outro (MONTOYA, 2010, p. 14). Isso demonstra que o outro não é extrínseco, mas intrínseco a si mesmo. Nessa dinâmica erótico-agapeica, a saciedade nos enche de um desejo de saborear sempre mais do

\footnotetext{
7 Sofia é Sabedoria (hokmá em hebraico) nas Escrituras Hebraicas. Às vezes, pode significar habilidade, capacidade artesanal; outras vezes, pode significar uma habilidade adquirida para a penetração intelectual e eloquência discursiva. Ao ser relacionada com o intelecto e o discurso, Sabedoria pode significar conhecimento, insight, e instrução. Para além da concepção moderna de conhecimento, a Sabedoria está intimamente relacionada com o coração, em uma dimensão de afetividade. Na Bíblia, a Sabedoria aparece como a personificação de uma mulher, mas também transgredindo a fronteira entre criatura e Deus. Sofia é um "híbrido" que se posiciona nas encruzilhadas, na fronteira entre homem e mulher, nativa e estrangeira, criatura e Deus, deuses e deusas (MONTOYA, 2008, p. 55-60).

8 Algumas de suas referências bíblicas: Prov 24, 13; Eclo 24, 15-20.
} 
“extravagante e excessivo" amor Divino, compartilhado na troca de dons no seio da Trindade. Extravagância que transbordou na criação, na encarnação e na Eucaristia, que é instrumento de nossa deificação, ponto de união extática entre a humanidade e Deus. Somos, portanto, seres famintos. Desejamos ardentemente o outro. Para Montoya, a semântica do erótico não remete simplesmente à carência, como sinalou Freud, mas ao desejo metafísico como um movimento contínuo para a plenitude agapeica, isto é, participação na comunhão intratrinitária.

"A raiz do erótico é este desejar um-outro-que-não-eu, um desejo de unir-me, extaticamente, com um outro" (MONTOYA, 2005, p. 13), isto é, o Ser Sofiânico é metaxológico9 (MONTOYA, 2010, p. 175). No metaxológico o Ser é relacionalidade sem uma resolução dialética final mediada pela subjetividade humana, pois está sempre aberta à Alteridade Absoluta. Isso significa que a própria individualidade, o autodiscernimento e a determinação não estão enraizados no próprio sujeito, mas no intercâmbio de dons. Isso não significa que o ser não seja satisfeito em seu desejo, que "passe fome”. Antes, ele é alimentado por Deus mesmo, que é "ato em excesso", o qual satisfaz toda a criação com um ato kenótico de nutrimento. Assim, em sua proposta de desconstrução do desejo, Montoya afirma:

O ser não é sinônimo de carência já que o nutre a superabundância de Deus, a qual é também uma dádiva do ato mesmo do ser. O Ser não se enraíza em si mesmo, senão que é ele generoso compartilhar do perpétuo 'ato de ser' de Deus. O ser, como Deus, é relacional. (MONTOYA, 2010, p. 185).

Nesta dinâmica o desejo, inserido na relacionalidade intratrinitária, é o movimento para o outro, para um deleitar-se no outro, em sua diferença. Como coreógrafo, Montoya imagina a dinâmica desta comunidade intratrinitária como um corpo dançante, como uma ação de quietude-movimento, como no ato perene de entregar-receber:

Nesta pericórese intratrinitária nunca ocorre a supressão da diferença numa igualdade centralizada, porque é precisamente no compartilhar-a-diferença que o ritmo e a dinâmica deste único fluxo perpétuo para além da unidade dançam. Esta imagem da dança de amor trinitário evoca a dinâmica infinita de Deus oferecendo à Alteridade o próprio dom de amor ao Outro, recebendo simultaneamente a gratuidade do amor do Outro; e essa reciprocidade extática impede a auto-aniquilação em virtude de sua ligação, testemunho e bênção

\footnotetext{
9 Metaxológico advém de metaxu, que em grego quer dizer "no meio", "intermédio" (MONTOYA, 2010, p.
} 175). 
perpétua de um terceiro - o Espírito Santo. O intercâmbio do dom na comunidade trinitária é ao mesmo tempo excesso e reciprocidade, e não acontece fora ou antes de ser dado, recebido e compartilhado (MONTOYA, 2005, p. 15).

Na linguagem da teologia alimentária, pode-se dizer que há em Deus uma infinita dinâmica de auto alimentação intratrinitária. E, é nessa pré-existência alimentaria que a teologia pós-secular estabelece seu fundamento. Nela está a origem, mas, sobretudo, o destino da humanidade, isto é, o escaton: a participação plena no superabundante banquete de Deus.

\subsection{A teo-política da superabundância}

Inserida na corrente contra moderna que nega a secularização, a teologia eróticoagapeica se constitui em uma instância crítica à secularização da razão e a idolatria que se constitui na ruptura com a fonte transcendente do sentido, que é identificado com o Mistério superabundante. Diante dos abusos do capitalismo e da razão instrumental - que segue explorando e dissecando os corpos e levando muitos a anorexia e morte por falta de pão essa teologia propõe a centralidade do nutrimento para a teologia nas sociedades cada vez mais fragmentadas. Por isso, pensa a possibilidade de construir sociedades inclusivas na diversidade humana, étnica, cultural, de gênero, política e religiosa.

Para isso, postula que a cognição seja entendida holisticamente, isto é, há de se buscar um conhecimento que envolva todo o ser: uma experiência tanto corporal como intelectual e afetiva; além de ser necessariamente aberta ao diferente. Essa teologia pós-secular para recuperar a afetividade, a sensibilidade, a sensualidade, a corporeidade, como instâncias de conhecimento e produção de saber - para além do objetivismo e do subjetivismo -, compreende o conhecimento, sobretudo aquele derivado do sentido do gosto, a partir da perspectiva da poiesis:

O conhecimento não é um acontecimento meramente 'interiorista' ou puramente 'exteriorista' senão que é, entretanto, um ato compartilhável, através do qual a interioridade se constitui através da exterioridade, e vice-versa. Enquanto que o sentido do gosto implica alguma forma de correspondência, não é um reflexo perfeito por meio do qual o corpo e o intelecto são meros registros epistemológicos passivos. De alguma maneira, o ato de degustar toca e constrói [...]. Isto significa que o sentido do gosto, como uma forma intensa de tocar, de fazer contato, também implica ser tocado, afetado, transformado, e inclusive destruído pelo ato de degustar. Por outro lado, o que tocamos também pode experimentar

INTERAÇÕES, Belo Horizonte, Brasil, v. 14, n. 25, p. 186-204, jan./jun. 2019

ISSN 1983-2478 
uma transformação [...]. É como se através do degustar, se faz o mundo, se re-cria ou reelabora. (MONTOYA, 2010, p. 111-112).

No ato da degustação experimentamos o mundo e pelo mundo somos experimentados. Somos por ele transformados e também o transformamos. Nessa reciprocidade, o conhecimento é interação contínua em uma multiplicidade de contextos. A Encarnação de Deus é o paradigma dessa assunção da materialidade, do diferente, do hibridismo originário, pois ao encarnar, Deus assume a carne humana em sua materialidade para divinizá-la. Deus assume a carne humana e a diviniza, sem violentá-la e, tampouco, transgredi-la. Ao contrário, com a encarnação, Deus a intensifica e a celebra, como um grande abraço:

Esta realidade da carne deleitando-se em um abraço divino apresenta a diferença não como in-diferença, senão como compartilhar e praticar a gratuidade recíproca. Mais ainda, a partir de uma perspectiva cristã, devido a que a carne de Cristo não é indiferente a carne como tal, se poderia conjecturar que este abraço divino (a Encarnação) nos deixa ver uma dimensão da afetividade e afinidade como algo prévio a diferença mesma. A carne de Cristo se alinha como o corpo humano. Na carne, Cristo mescla os desejos de Deus com os desejos da humanidade (MONTOYA, 2010, p. 74-75).

A Encarnação, então, constitui-se em um híbrido de desejos divinos e desejos humanos. Esta hibridização revela a dimensão de mestiçagem entre o divino e o humano, sem, contudo, anular as diferenças. Tal como foi estabelecido pelo princípio de Calcedônia. Mais do que isso, essa hibridização aponta para aquela dimensão da poeisis, a que toda a humanidade é convidada a assumir, isto é, que a dimensão estética suscita uma exigência ética e política. Todos somos chamados a uma ação prática que transforme o mundo através do poder de um "corpo habitado pela força do amor que transfigura a pessoa e seu contexto vital desde a acepção de suas pulsões eróticos-agapeicas”, como bem apontou o teólogo Carlos Mendoza Álvarez (2015, p. 331). Através da degustação, sobretudo da Eucaristia, somos transfigurados e nossa subjetividade é potencializada pela criatividade sofiânica, para uma teo-política. Esta se concretiza no desejo como perpétuo processo alimentário da criação que deriva da superabundância divina:

A teopolítica do Corpo de Cristo se enraíza não exclusivamente no poder, mas sim e em um sentido mais primordial, na caritas divina, expressada com um gesto radical de kenosis, reciprocidade, e práticas coletivas concretas (MONTOYA, 2010, p. 194). 
Não se trata aqui de uma renúncia ao poder, ou desempoderamento, mas um poder outro. Evidente que há uma política do poder. Entretanto, um poder análogo à plenitude do desejo que se expressa no sacrifício na cruz. É, com efeito, um não-poder que transforma o pão em migalhas para compartilhar com todos. Em outro marco teológico, Carlos Mendoza (2010, p. 277) fala do "poder-do-não-poder”, aquele poder de habitar o mundo violento na força do "Crucificado-que-Vive"; que capacita a subjetividade a transfigurar o mundo violento pela oferenda de si mesmo em prol da instauração da Civitas Dei. Trata-se de viver no mundo com o desejo desconstruído da rivalidade, na assunção da lógica da gratuidade (CALDEIRA, 2019, p. 1-25). É, com efeito, uma tentativa de reabilitar o corpo de carne no processo da redenção humana. Nesse horizonte, Tertuliano já havia anunciado de forma magistral que "a carne é a charneira da salvação (caro salutis cardo)". Para o Pai da Igreja a "carne é o instrumento de salvação" (SESBOUÉ, 2001, p. 220). Assim, pode-se dizer que na perspectiva da teologia alimentária fora do corpo erótico-agapeico não há salvação. De maneira que a expressão "Isto é meu corpo" enquanto sacramento maior, fala da entrega de si mesmo em prol dos outros, como nutrimento.

Trata-se, com efeito, de uma existência inerentemente “eucarística”, na qual o banquete eucarístico torna-se um signo de uma subjetividade aberta ao dom. Uma entrega de si mesmo que transfigura a fome em saciedade e o individualismo em festa coletiva. $\mathrm{E}$ ainda mais, trata-se de uma existência que deifica toda a humanidade e toda a criação através da encenação do banquete cósmico-divino. Em um "deleite kenótico”, um alegre desapego que busca alimentar o Outro concreto em contraposição a um Outro abstrato (MONTOYA, 2010, p. 185).

Partindo de outro marco referencial, Carlos Mendoza (2015, p. 258) comentando a teologia erótico-agapeica sublinha que "todo ato de nutrição relacional é um gesto messiânico que antecipa o fim dos tempos e a chegada do Reino de Deus":

Esta experiência fundacional da "nutrição originaria" que constitui ao ser certamente denuncia a experiência de fome e da indigência, embora também anuncia a força da mão aberta que compartilha e por sua vez espera algo mais que 'as migalhas que caem da mesa do amo'. Com efeito, no paroxismo de sua entrega, o ato de nutrição erótico-agapeico é sobretudo um ato de doação gratuita, de mesa servida. (MENDOZA, 2015, p. 337).

Assim, para Carlos Mendoza, ao alimentar o outro que tem fome, no puro ato de gratuidade, abrem-se "lascas na história" [célebre expressão consagrada por Walter Benjamin] por meio das quais acontece a manifestação do Mistério Superabundante. Mais 
que permanecer na mera reciprocidade, é preciso dar o salto qualitativo na história, e por meio dos gestos de extrema gratuidade, criar um espaço de intersubjetividade que redime a todos por meio de sua existência erótico-agapeica. Isso só é possível àquela subjetividade que se encontra unida à sua Fonte de superabundância divina, como origem e destino de toda a subjetividade em doação (CALDEIRA, 2018, p. 141-159).

\section{NARRATIVA DO PROTAGONISMO DÉBIL DE DEUS}

Em sua leitura antropológica da Bíblia judaico-cristã, René Girard concluiu que no relato bíblico há uma revolução da lógica sacrificial, na qual a narrativa bíblica desvenda a mentira da Satã e revela a verdade de Deus enquanto superação da violência fratricida (GIRARD; CHANTRE, 2011, p. 21-33). Para o antropólogo, a lógica sacrificial constitui a base estrutural de todas as culturas que se tem registro. Segundo as análises de Girard, não temos notícias de sociedade pacíficas, mas todas as sociedades que temos memória estão sob o "signo de Caim" (MENDOZA, 2008, p. 33)10. O desejo mimético é, portanto, a forma histórica de ser-no-mundo. Porém, no seio destas sociedades cainescas, sempre existiram pessoas que vivem em pura gratuidade, agindo na contramão do desejo mimético, abrindo caminhos de reconciliação e paz; mesmo que isso resulte no próprio aniquilamento. Isso acontece, porque estas pessoas apostam em outra maneira de ser-no-mundo e vislumbram a irrupção de um novo mundo. Estes são os justos da história, tal como foi Jesus de Nazaré (ALISON, 2011, p. 61) ${ }^{11}$.

Assim, Girard descobre que a Bíblia retrata a mesma história fratricida, porém de maneira totalmente inversa, isto é, a partir da vítima e não de seu duplo mimético, ou seja, do verdugo que sempre tenta justificar a execução do inocente. No relato bíblico, a inocência da vítima será descoberta in crescendo. De Abel até os relatos da Paixão de Cristo esse anúncio tomará lugar, quando este será sacrificado pelo povo, segundo a lógica de Caifás ${ }^{12}$.

\footnotetext{
${ }^{10} \mathrm{Em}$ geral, se critica a teoria girardiana por um pessimismo antropológico que afirma a inveja original. Porém, em sua teoria não se trata de afirmar uma inveja ontológica, mas sim de potencializar a imaginação escatológica daquelas pessoas que, apesar dos verdugos seguirem triunfando, insistem em dar suas vidas pelos demais (MENDOZA, 2008, p. 33, grifo nosso).

${ }^{11}$ Exatamente aqui temos os dois polos da antropologia da sabedoria ou de conversão desenvolvida por James Alison, a saber: "o que é recebido gratuitamente e o que é obtido com esforço". Nesta antropologia da sabedoria, ele afirma que existe uma antropologia da revelação presente nos Evangelhos e se trata da antropologia do desejo mimético. Jesus detinha uma compreensão antropológica muito semelhante à do desejo mimético. E os discípulos foram aos poucos consolidando essa compreensão, em um processo árduo de conversão (ALISON, 2011, p. 61).

12 "É melhor que um só homem morra pelo povo" (João 18, 14).
} 
Mas, o triunfo da cruz consiste, exatamente, na inversão da mentira de Satã. Essa é a especificidade do cristianismo que, segundo Girard, alcançou a revelação da verdade antropológica capaz de subverter a lógica sacrificial (MENDOZA, 2010, p. 263)³; quando a vítima crucificada retorna para os seus, não para se vingar, mas para perdoá-los. Contudo, mesmo tendo alcançado tal verdade antropológica, Girard afirma que o cristianismo fracassou em fazer a humanidade sair do estágio do desejo mimético violento e entrar no estágio da maturidade; para além da falácia da reciprocidade (MENDOZA, 2010, p. 268)14.

Apropriando-se da teoria do desejo mimético de René Girard, James Alison constrói sua peculiar teologia assumindo a irreversível autonomia das realidades terrestres ${ }^{15}$. Assim, ele desenvolve uma hermenêutica bíblica em chave mimética, na qual compreende como fio condutor de toda a Escritura a progressiva revelação da "vítima perdoadora" (the forgiving victim), que revela o protagonismo de Deus. Vejamos dois aspectos de sua teologia, a saber: o colapso do ego: aprendendo a chamar Deus de Abba e a revelação de Deus por meio da "vítima perdoadora".

\subsection{O colapso do ego: aprendendo a chamar Deus de Abba}

Partindo de sua própria experiência conflitiva, enquanto sacerdote católico assumidamente gay, Alison (2010, p. 65-99) desenvolverá sua reflexão teológica “a partir das pedras e do pó", no qual a "vergonha" torna-se locus theologicus. A vergonha como horizonte de "assunção radical da vulnerabilidade do sujeito" em perspectiva de abertura e esperança (MENDOZA, 2015, p. 315), próprio do dinamismo da subjetividade pós-moderna

\footnotetext{
$13 \mathrm{O}$ bode expiatório - atestado pela cultura hebraica antiga - é o princeps analogatum daquela paradoxal simbólica que está em todas as culturas e religiões da humanidade. Para Girard, a religião se converte então naquele fundo de verdade do real mimético. Nesse sentido que o real não é racional; o real é religioso, e religioso sacrificial. Essa é a chave de interpretação antropológica da condição humana de Girard. A Bíblia judaica e cristã virá revolucionar essa lógica do mecanismo mimético para mostrar sua mentira profunda e desvelar a verdade de Deus enquanto superação da violência fratricida. A Bíblia conta a mesma história fratricida, mas de um modo inovador: a partir da vítima e não de seu duplo mimético, ou seja, do verdugo que sempre tenta justificar a execução do inocente. A revelação da inocência da vítima será descoberta in crescendo pela Bíblia, sobretudo graças à sua tradição profética e messiânica (MENDOZA, 2010, p. 263).

14 Girard considera que historicamente o cristianismo fracassou no Ocidente tanto quanto o racionalismo moderno. Razão de nos encontrarmos em meio à violência extrema que ameaça a todos, inclusive ao planeta. Ver MENDOZA, 2010, p. 389-409.

15 Teologia que James Alison desenvolve há mais de vinte anos. Suas principais obras são: El retorno de Abel: las huellas de la imaginación escatológica (ALISON, 1999); Fé além do ressentimento: fragmentos católicos em voz gay (ALISON, 2010); e $O$ pecado original à luz da ressurreição: a alegria de descobrir-se equivocado. (ALISON, 2011).
} 
enquanto descobre-se um ser finito e aberto à alteridade. Na tentativa de iluminar este pano de fundo, Carlos Mendoza recorda-nos que:

Trata-se de uma subjetividade consciente de suas pulsões de desejo, com toda a carga de sonhos de onipotência, manipulação, mimetismo e sedução que comporta toda relação ao outro e ao Outro. Mas o que importa é o horizonte de compreensão que emerge desta experiência: a possibilidade de receber-se como uma pessoa incondicionalmente amada pela alteridade inefável que chamamos Deus. (MENDOZA, 2015, p. 242).

Encontrando-se "incondicionalmente amado por Deus", Alison desenvolverá sua hermenêutica bíblica que vai relevando um processo de "reversão" na construção de uma subjetividade aberta ao dom. Essa reversão só é possível depois do colapso do ego, no qual precisamos aprender, “a partis das pedras e do pó”, isto é, do colapso do sagrado violento e do ego, a ouvir "o novo tom da voz de Deus" (ALISON, 2008, p. 39-53). Para Alison, não se trata de uma voz propriamente dita, mas sim daquele protagonismo que é Deus, que irrompe diretamente na subjetividade e sacode a estrutura do eu ensimesmado e inicia um processo de derrubamento dos ídolos. O protagonismo de Deus revela-se sempre por meio daquele “protagonismo forte da presença débil” - a vítima perdoadora-, a qual encontrou sua revelação plena na autodoação de Jesus de Nazaré. Mas que também é percebida por intermédio de todas as vítimas inocentes da história que aprendem a perdoar, visto que o perdão nos é ofertado somente através da vítima que conseguiu superar o ressentimento e a rivalidade, movendo-se na lógica da gratuidade. Com a vítima não ressentida se instaura a verdadeira relação de alteridade, na gratuidade pura, na qual um novo mundo torna-se possível (ALISON, 2008, p. 39-53).

Essa "vítima perdoadora” torna-se a "presença densa" que passa a ser a força motriz da humanidade. Com a vítima que perdoa o poder do amor recriador de Deus manifesto em Jesus abre caminho para se acessar o Fundo misterioso do real, isto é, Deus em linguagem monoteísta:

Se toda a maneira de se fazer presente Deus em nosso meio é precisamente o protagonismo forte da presença débil, então nos chega como um processo de descobrirmos equivocados, atados, dependentes de outros protagonismos e outras forças na medida em que nos deixamos interpelar pela força daquela generosa debilidade. E é a partir de receber aquele perdão, que toma a forma de ficar libertos, soltos para a soltura, que entramos no processo de notar a mudança nos tons da voz de Deus. (ALISON, 2008, p. 48-49). 
Dessa perspectiva da debilidade do protagonismo de Deus, a kénosis torna-se o “princípio hermenêutico" da verdadeira adoração. Esta, por sua vez, é fruto de um longo e árduo processo de participação no colapso do sagrado violento - que subsiste em virtude das vítimas que sacrificam - capaz de criar um espaço onde caibam todas as diferenças. Isso se faz através da superação do ressentimento e da rivalidade. Assim, torna-se indispensável a criação de um espaço para um coração despedaçado, à beira do abismo. Isso significa um espaço onde aprendemos a nomear Deus a partir do colapso do próprio eu e das formas do sagrado sacrificial; um espaço onde reconhecemos nossa culpabilidade e participação nesse sagrado sacrificial. Não apenas isso. Mas, também, um espaço onde aprendemos a nomear o outro, como próximo, constitutivo do próprio eu. E, assim, aprender a dizer um “nós”, isto é, a criar um espaço verdadeiramente eucarístico, um espaço intersubjetivo. A criação desse espaço se torna possível quando experimentamos o poder de sermos perdoados.

Do protagonismo débil, com sua expressão máxima em Jesus de Nazaré, acontece uma subversão também na ideia de pecado. Este deixa de ser um defeito, uma prática que não se enquadra nos padrões do "grupo dos justos", tornando-se a própria participação no mecanismo de expulsão (ALISON, 2011, p. 220). Pecado é resistir, em nome de Deus, ao trabalho criador de incluir a todas as pessoas no banquete eucarístico ${ }^{16}$. Nisto consiste a singularidade da fé, ela:

Oferece-nos a dinâmica da subversão, desde o interior de todas as virtudes humanas, incluindo as nossas práticas. Isso equivale a dizer que o começo da vida moral cristã é marcado por um tropeço que leva à consciência de nossa própria cumplicidade nos mecanismos de hipocrisia, pela percepção da violência envolvida nessa hipocrisia. (ALISON, 2010, p. 63, grifo nosso).

Do lugar do colapso do sagrado e de uma real demolição de nossas estruturas pessoais e modos de dizer Deus, se inicia a subversão, ou melhor, a conversão para um novo eu. Não um eu constituído em rivalidade com o outro, tampouco uma relação de reciprocidade, mas uma "existência em doação", pura gratuidade. Isso é possível, se partir daquela subjetividade

\footnotetext{
16 "O pecado é revelado como o mecanismo de expulsão cujo funcionamento é homicida e os pecadores cegos são todos aqueles que estão envolvidos nesse mecanismo, sem se darem conta do que estão fazendo. $\mathrm{O}$ problema maior não está com aqueles que são apenas parte cega do mecanismo de exclusão: eles, ao menos, não sabem o que estão fazendo e, portanto, não são culpados. O grande problema [está] com aqueles [...] que compõem, integram e manipulam tais mecanismos de exclusão, pois pensam que 'podem ver', ou seja, pensam possuir insight moral, separar o bem do mal, julgando-se capazes de discernimento e julgamento. Essas pessoas não apenas tomam parte dos violentos mecanismos de exclusão, mas os justificam como bons e vindos de Deus. A culpa deles permanece." (ALISON, 2011, p. 202).
} 
que, tendo experimentado em seu próprio corpo a morte, nada teme perder, se encontra incondicionalmente amada por Deus (ALISON, 2010, p. 88).

Esse é o singular lugar no qual podemos dizer: Abba (Pai). Não porque recebemos uma revelação como raio, revelando-nos verticalmente o rosto paterno de Deus. Ao contrário, antes, por meio do aprendizado com Jesus de Nazaré vamos entendendo que a paternidade deste mundo é, na verdade, mítica e idólatra. Trata-se, no fundo, de uma fraternidade fratricida desde Abel e Caim, isto é, desde a fundação do mundo. Assim, Alison desconstrói o desejo ao afirmar que a "estrutura de nosso desejo, cuja existência precede nossa consciência, é homicida" (ALISON, 2010, p. 110-111). Não no sentido freudiano, no qual a paternidade biológica é o modelo-base para uma paternidade cultural distorcida, antes, o inverso: uma fraternidade cultural distorcida modela a paternidade biológica, não fraternal.

Se realmente desejamos conhecer a Deus como Pai, isso equivale a sair do estágio da infantilidade, não existe outro caminho a não ser aquele de uma fraternidade e sororidade não sacrificial que reconhece sua culpabilidade nos mecanismos sacrificiais, sob os quais a ordem social está estruturada. Porque, "a verdadeira natureza de Deus se descobre não por meio da verticalidade de uma paternidade que se impõe, mas pela horizontalidade de uma fraternidade que se vive”, afirma João Batista Libânio ao fazer o prefácio do livro de Alison (2010, p. 9). Nisso consiste o verdadeiro culto a Deus.

\subsection{A revelação de Deus por meio da "vítima perdoadora"}

A ressurreição, isto é, a aparição da “vítima perdoadora”, é o princípio hermenêutico do verdadeiro culto a Deus. A partir da aparição do Crucificado-que-vive as discípulas e os discípulos irão perceber que a densidade da presença de Jesus Ressurreto é uma presença "fundamentalmente" outra. Uma presença agraciadora constituída do perdão; melhor, a própria “encarnação do perdão" (ALISON, 2011, p. 136). A experiência das discípulas e dos discípulos ante o Crucificado-que-vive desencadeia um processo de desconstrução da imagem de Deus e da imagem do ser humano, pois a "vítima perdoadora" retorna não para se vingar, mas para perdoar. É a aparição de algo totalmente novo na história da humanidade.

Jesus aparece às suas discípulas e aos seus discípulos como simultaneamente morto e vivo. Tornando-se desde sua morte uma densa presença como o Crucificado-que-vive. É a 
revelação de um amor para além da morte. Não somente isso. Mas, também, revela e desmantela o sistema que crucifica os inocentes por meio do contágio mimético.

Alison demonstra cuidadosamente que, por meio do processo de "imaginação escatológica”, ou seja, através da releitura das Escrituras hebraicas à luz da ressurreição, as discípulas e os discípulos vão descobrir a "inteligência da vítima” (ALISON, 2011, p. 142)17. Esta se torna chave hermenêutica para desmantelar os mecanismos de violência, a partir da oferta do perdão gratuito por parte da vítima. As discípulas e os discípulos à luz da ressurreição descobrem que Jesus durante toda a sua vida tinha consciência da realidade de Deus e dos seres humanos. Sua compreensão da realidade desencadeou o mecanismo mimético, que culminou em sua morte. Foi a ressurreição que tornou acessível às discípulas e aos discípulos essa inteligência de Jesus (ALISON, 2011, p. 142)18.

A “inteligência da vítima”, desta forma, enquanto potência do crucificado possibilitou as discípulas e aos discípulos a enxergarem progressivamente a história de sua execução e de todas as vítimas da história. Não mais da perspectiva do vencedor, mas do ponto de vista da vítima. Porém, não uma vítima qualquer, mas a vítima que volta não ressentida, que se assume enquanto uma "existência em doação". Assim, à luz da ressurreição, nesse mundo, “a percepção de uma presença humana puramente gratuita é vista como inteligência da vítima” (ALISON, 2011, p. 146).

A “inteligência da vítima” torna-se, então, a potência mesma de uma nova expressão humana, capaz de subverter a consciência humana presa nos mecanismos vitimários, isto é, na violência fratricida. Longe de ser apenas uma iluminação, a "inteligência da vítima" é revelação "criadora e construtiva" do processo de um novo modo de ser-no-mundo, mutuamente reconciliados. A intuição dessa verdade revelada da "inteligência da vítima", antes de ser um dado teológico, é uma verdade antropológica. E, enquanto tal, diz respeito a todas as sociedades humanas, as quais se estruturam sob o sacrifício das vítimas, e são cegas à cumplicidade que têm no mecanismo vitimário fundador. Razão pela qual a vítima

\footnotetext{
17"Essa inteligência, que os apóstolos compreenderam ser a dinâmica interna a inspirar toda a vida e a morte de Jesus, aquilo que formara seu relacionamento com o Pai, resolvi chamar aqui de inteligência da vítima" (ALISON, 2011, p. 142).

${ }^{18}$ Alison diz: "À medida que foram possuídos por essa inteligência, os discípulos começaram a reler todo o processo, que desembocou na morte de Jesus, como a história da vítima que se doa e se revela, numa dinâmica em que apenas a vítima em questão sabia o que realmente estava acontecendo. Eles se tornaram capazes de entender que a morte de Jesus não fora uma interrupção abrupta e acidental de uma carreira que se encaminhava em outra direção, mas, pelo contrário, compreenderam que toda a sua vida fora vivida de uma maneira peculiar, cujo sentido corria em direção àquela morte e que Jesus estivera o tempo todo consciente disso" (ALISON, 2011, p. 142).
} 
que se doa gratuitamente torna-se a única possibilidade de nova configuração da humanidade. Diferente de Caim, Abel assume o prototípico do justo de todos os tempos (ALISON, 1999). Nessa perspectiva, Alison desvela o único, singular e irrepetível fundamento da Ecclesia: a "vítima perdoadora", que se doa por amor. (ALISON, 2011, p. 157-158).

Esta antropologia teológica de James Alison constitui-se, na verdade, em uma escatologia pós-moderna. Neste sentido, Carlos Mendoza, partindo da teologia da libertação latino-americana, relê aquele antigo axioma soteriológico: Extra Ecclesiam nulla salus (Fora da Igreja não há salvação) (MENDOZA, 2013, p. 336). Ele recupera de Agostinho a expressão Ecclesia ab Abel, que diz "a Igreja que existe desde Abel o justo", para explorar outra semântica ao antigo axioma soteriológico. Este princípio hermenêutico, desenvolvido por Agostinho e outros Padres da Igreja, possibilita hoje reafirmar que "a Igreja subsiste desde Abel o justo" como resposta de Deus ao clamor dos inocentes vitimados. Nessa perspectiva, o adágio "fora dessa Ecclesia não há salvação possível para a humanidade” permanece vigente. Contudo, a Igreja parece designar em si a "comunidade de inocentes vitimados”, cujo sangue clama ao céu desde o primeiro fratricídio que se tem registro na história. Assim,

O sangue derramado de Jesus de Nazaré se encontra intimamente associado ao de todos os inocentes vitimados e a experiência da ressurreição, anunciada por seus discípulos, é compreendida como retorno de Abel para redimir a todos a partir do perdão que cura e dignifica a vida desprezada, instaurando, assim, a redenção. (MENDOZA, 2013, p. 327).

Carlos Mendoza, assim, para dar conta da vulnerabilidade constitutiva da subjetividade, partindo da "difícil doação"19, afirma que as vítimas são portadoras da “contração do tempo messiânico". Elas instauram uma temporalidade redimida de sua violência, isto é, a temporalidade messiânica quando elas conseguem desatar pelo "amor não recíproco", tampouco simétrico, as ataduras da rivalidade e do ressentimento. Da subjetividade enquanto “existência em doação” se iniciará a chegada do Reino de Deus, esta

\footnotetext{
19 Difícil doação é a via antropológica pós-moderna, que evoca o processo de subversão do desejo mimético que instaurou Jesus de Nazaré, porém muitos outros "contemporâneos messiânicos" também o vivenciou com análoga profundidade existencial. A "difícil doação" é um estágio da subjetividade que não se move sob a lógica da reciprocidade, visto que esta sempre conduz à violência e exclusão; tampouco se fecunda no eterno retorno do ressentimento experimentado no presente e projetado à vida eterna. Antes, esse estágio da subjetividade como doação, advém da experiência dos gestos gratuitos e inesperados dos invisibilizados pelos sistemas de totalidade e de onipotência. (CALDEIRA, 2017, p. 829).
} 
se concretiza como contra história messiânica. Daí a expressão: Extra victimas nulla sallus est (Fora das vítimas não há salvação) (MENDOZA, 2013, p. 340). Porque por meio das vítimas chega a redenção para todos, tanto para as vítimas como para os verdugos em sua impotência de serem absolvidos por si mesmos; pois dos verdugos sobe um clamor por redenção e sua finitude, de sua culpabilidade e violência sacrificial que suplanta o sagrado.

\section{CONSIDERAÇÕES FINAIS}

Neste contexto de derrubamento da cristandade e a urgente necessidade de dizer Deus e o humano em meios aos escombros, percebe-se que estas antropologias da vulnerabilidade ensaiam - cada uma a seu modo e no seu contexto específico - um balbucio sobre o Mistério do Real. Diante da crescente exclusão da globalização e do capitalismo que disseca a humanidade, cresce a cada dia os seres que têm fome. Nesse sentido, parece pertinente falar de Deus a partir de sua superabundância que nos capacita a partilhar o pão a quem tem fome. Recordemos que no marco da teologia alimentária, a fome no contexto pós-moderno não se reduz à fome de pão. Antes, também é fome de afeto, de justiça, de verdade e de amor. Fazer teologia na cozinha e sob a mesa significa não se esquecer daquelas subjetividades vulneráveis e vulneradas que anseiam participar do banquete como filhas e filhos amados de Deus, o Abba de Jesus.

Parece, ademais, que já não podemos fechar os olhos e tampouco os ouvidos para o grito das vítimas de nossos tempos. Parece impossível fazer teologia fora dessa experiência de exclusão e morte que gera ressentimento e ódio. Entretanto, somente uma teologia da fraqueza de Deus pode dar voz e vida às vítimas da história. Somente uma experiência de nos descobrirmos cúmplices dos processos de rivalidade e exclusão pode nos inserir num processo de subversão do nosso ego e assim iniciarmos a escuta do Mistério amoroso que sempre passa nos salvando. Outrossim, aceitar o convite do banquete escatológico parece estar indissociável da oferta do perdão por parte da vítima que sabe perdoar.

\section{REFERÊNCIAS}

ALISON, James. El retorno de Abel: las huellas de la imaginación escatológica. Barcelona: Helder, 1999.

ALISON, James. Los câmbios de tono em la voz de Dios: entre el deseo divino y la marea humana. In: MENDOZA ÁLVAREZ, Carlos. Cristianismo posmoderno o 
postsecular? Por una interpretación teológica de la modernidade tardía. Mexico: Universidad Iberoamericana, 2008, p. 39-53.

ALISON, James. Fé além do ressentimento: fragmentos católicos em voz gay. São Paulo: É Realizações, 2010.

ALISON, James. O pecado original à luz da ressurreição: a alegria de descobrir-se equivocado. São Paulo: É Realizações, 2011.

CALDEIRA, Cleusa. Teologia e niilismo pós-moderno: a subjetividade vulnerável como locus theologicus no pensamento de Carlos Mendoza Álvarez. Revista Pistis \& Práxis 9, n. 3, p. 810-838, 2017.

CALDEIRA, Cleusa. Cristianismo pós-moderno: midrash do tempo messiânico segundo a teologia de Carlos Mendoza Álvarez. Theologica Xaveriana, 187, p. 1-25, 2019.

CALDEIRA, Cleusa. Fundamentos teológicos da política: reabilitação da fonte política da subjetividade em tempos pós-modernos. REVER, v. 18, n. 3, p. 141-159, 2018.

ESTRADA, Juan Antonio. El movimento de “Ortodoxia radical”. In: ZEPEDA, José de Jesus L. (Coord.). Religión y secularización en una sociedade postsecular. México: 2010, pp. 99-119.

GIRARD, René; CHANTRE, Benoît. Rematar Clausewitz: além da guerra. São Paulo: É Realizações, 2011.

MENDOZA ÁLVAREZ, Carlos. Entre nihilismo y vuelta al fundamento. In: MENDOZA ÁLVAREZ, Carlos. (coord.). ¿Cristianismo posmoderno o postsecular? Por una interpretación teológica de la modernidad tardía. México: Universidad Iberoamericana, 2008, p. 17-36.

MENDOZA ÁlVAREZ, Carlos. El Dios escondido de la posmodernidad. Deseo, memoria e imaginación escatológica. Ensayo de teologia fundamental posmoderna. Guadalajara: SUJ, 2010.

MENDOZA ÁLVAREZ, Carlos. Extra victimas salus non est ou da vigência da teologia da libertação em tempos pós-modernos. In: BRIGHENTI, Agenor e HERMANO, Rosário. A teologia da libertação em prospectiva. Congresso Continental de teologia. São Paulo: Paulus/Paulinas, 2013, p. 323-341.

MENDOZA ÁLVAREZ, Carlos. Pensar a esperança como apocalipse. Conversa com René Girard”. In: MENDOZA ÁLVAREZ, Carlos. El Dios escondido de la posmodernidad. Deseo, memoria e imaginación escatológica. Ensayo de teologia fundamental posmoderna. Guadalajara: SUJ, 2010, p. 389-409.

MENDOZA ÁLVAREZ, Carlos. Deus ineffabilis: una teologia posmoderna de la revelación del fin de los tiempos. Madrid: Helder, 2015.

MILBANK, John. Teologia e teoria social para além da razão secular. São Paulo: Loyola, 1995. 
MONTOYA, Ángel Francisco Méndez. Alimentação divina: gastroerotismo e desejo eucarístico. Concilium, n. 310, v. 2, p. 11-20, 2005.

MONTOYA, Ángel Francisco Méndez. El banquete de Sofia: una visión de la comunidad erótico-agapéica. In: MENDOZA ÁLVAREZ, C. (Coord.). Cristianismo pós-moderno o postsecular? Por una interpretación teológica de la modernidad tardía. México:

Iberoamericana, 2008, p. 55-68.

MONTOYA, Ángel Francisco Méndez. Festín del deseo: hacia uma teología alimentaria. México: Jus, 2010.

SESBOUÉ, Bernard. Convite a pensar e viver a fé no terceiro Milênio: sacramentos credíveis e desejáveis. v. 2. Coimbra: Gráfica de Coimbra, 2001.

Recebido em: 16.05.2018 Aprovado em: 24.04.2019 